\title{
Hydraulic conductivity and calcium carbonate content of biocemented heavy-metal contaminated mine waste soil
}

\author{
Jodin Makinda ${ }^{1,2 *}$, Khairul Anuar Kassim ${ }^{1}$, Kamarudin Ahmad ${ }^{1}$, Abubakar Sadiq Muhammed ${ }^{1,3}$, and Muttaqa Uba \\ Zango ${ }^{1,4}$ \\ ${ }^{1}$ School of Civil Engineering, Faculty of Engineering, University of Technology Malaysia, 81310, Johor Bahru, Johor, Malaysia \\ ${ }^{2}$ Faculty of Engineering, University of Malaysia Sabah, 88400, Kinabalu, Sabah, Malaysia \\ ${ }^{3}$ Department of Civil and Water Resources Engineering, Unimaid, P.M.B. 1069 Maiduguri, Borno State, Nigeria \\ ${ }^{4}$ Department of Civil Engineering, KUST, Wudil P.M.B. 3244 Kano State, Nigeria
}

\begin{abstract}
It is not uncommon for mining activity to generate wastes associated with negative engineering impacts include susceptibility to runoff due to the absence of vegetation, erosion, and sinkhole. Due to their high degree of permeability, movement of heavy metal contaminants in waste soils and aquifers occurs actively along with the hydrogeological parameters, and research on using biocementation methods such as enzyme induced calcite precipitation (EICP) to reduce the hydraulic conductivity is therefore beneficial. Mine waste soil collected from a copper mine in Lohan Dam, Sabah is characterized physically, morphologically, and chemically then treated with EICP under different operational parameters include curing duration $(1,3,7$ days), curing temperatures $(5,10$, and $25{ }^{\circ} \mathrm{C}$ ), and relative density $(70$ and $80 \%)$. The hydraulic conductivity was then tested using a constant head permeability test and the calcium carbonate content (\%) is determined using the HCL washing method. Properties of the Lohan Dam wastes are found to be predominantly coarse grain soil of low plasticity, high specific gravity, high permeability, acidic in nature, and low organic content. Morphologically, they are composed of powdered and hardened particles with dark brown color with high amount of irregular-shaped particles. Mineralogical, Lohan Dam soil wastes contain a high level of heavy metals beyond the safety level of the Department of Environmental Malaysia. EICP treatment had to change the degree of permeability from 'high and medium' to 'low' with a 94-97\% reduction in hydraulic conductivity corresponding to the amount of calcium carbonate content produced ranging $6.94-9.63 \%$. In conclusion, relative density shows the marginal effect, curing duration, and temperature shows a more significant impact on the treatment effectiveness.
\end{abstract}

\section{Introduction}

The mining process generates a large number of inert materials but the presence of toxic heavy metals such as mercury, arsenic, lead, zinc, cadmium is not uncommon. Hazardous chemicals may present naturally or due to addition during the extraction process. The potential threat of these contaminants to the environment sustainability may include alteration of soil composition and threatening the quality of water supply and groundwater. As a consequence, the living quality especially of the population living around the surrounding area is low, in some cases forcing resettlement and changing their economic structure.

In addition, negative engineering impacts include susceptibility to runoff due to the absence of vegetation, erosion, and sinkhole due to highly permeable soil, and landslide due to unstable grounds, which may increase because of the debilitated properties of soil. As a result, rupture of ponds, dams, or impoundments that can flood the adjacent lands is a real threat. As the movement of contaminants especially in soils and aquifers often occurs along with the hydrogeological parameters, study on remedial methods such as biocementation using enzymeinduced calcite precipitation (EICP) is necessary. Since EICP is considered relatively new, more inventive, and environmentally sustainable compared to the other methods, a wider application of this technique in geotechnical engineering should be explored.

Most of the current researches on EICP deals with improving the strength of either organic, clayey, or sandy soils. Limited available data on how the method can be applied in mine waste management, thus the necessity of this research. This paper reports the investigation of the performance of EICP in terms of reduction of the hydraulic conductivity of heavy-metal contaminated mine waste and the calcium carbonate content is produced.

\section{Literature Review}

Soils are the major end-recipient of the heavy metals released into the environment and unlike organic

*Corresponding author: jodin@ums.edu.my 
contaminants that can be oxidized by microbial activity, most metals do not undergo chemical degradation, therefore their concentration stays in the soil long after their introduction [1]. In Sabah, Malaysia one of the mines that have been known to pose health and environmental risk is the Mamut Copper Mine (MCM) located in the interior part of Ranau District. The mine was in operation from 1975 to 1999 and during this period, it generated about $350 \mathrm{Mt}$ of waste, of which $250 \mathrm{Mt}$ are rocks and overburdened materials and over $100 \mathrm{Mt}$ of tailings. The wastes were dumped at various sites near the mining areas but mostly at nearby Lohan Dam [2].

Investigation on the geotechnical properties of heavy metal-contaminated soil provided varied characteristics when different sources and localities are investigated. Researchers comparing iron mine in China and copper mine in Mexico reported the differences in their basic geotechnical properties, permeability, compression, and cyclic response [3], while a study on geotechnical properties of a clay soil from old tin mines in Pahang, Malaysia showed variances in compaction properties, consistency index, shear strength and permeability [4]. The differences in soil behaviors can be respectively attributed to their ore type, clay mineralogy and physical and chemical process used during extraction stages [3], and different percentages of tin tailings [5].

Ground improvement methods and techniques particularly on the enhancement of engineering properties of heavy metal contaminated soil can be divided into physical, chemical, or biological techniques. Physical improvement methods are soil replacement, thermal analysis, or electric repair, chemical treatments are either through passivation or leaching and biological remediation (or bioremediation) methods include pytoremediation and animal repair. However, these methods are considered costly for a small-scale project, not completely effective, or maybe cause secondary pollution, questionable long-term durability, limited heavy metal enrichment, slow and long treatment cycles [6]. Moreover, for bioremediation, different heavy metals may have different effects on the biochemical functions of the animals [7]. Therefore, the aforementioned limitations of these practices necessitate exploration for environmentally-friendly and sustainable technologies hence utilization of biological processes such as EICP, a biologically driven calcium carbonate (calcite or $\mathrm{CaCO}_{3}$ ) precipitation technology, either controlled or induced.

The mechanism of the EICP is summarized in Eq 1-6 below [8],

$$
\begin{aligned}
& \mathrm{CO}\left(\mathrm{NH}_{2}\right)_{2}+\mathrm{H}_{2} \mathrm{O} \stackrel{\text { urease enzyme }}{\longrightarrow} \mathrm{NH}_{3}+\mathrm{NH}_{2} \mathrm{COOH} \\
& \mathrm{NH}_{2} \mathrm{COOH}+\mathrm{H}_{2} \mathrm{O} \rightarrow \mathrm{NH}_{3}+\mathrm{H}_{2} \mathrm{CO}_{3} \\
& 2 \mathrm{NH}_{3}+2 \mathrm{H}_{2} \mathrm{O} \rightarrow 2 \mathrm{NH}_{4}^{+}+2 \mathrm{OH}^{-} \\
& 2 \mathrm{OH}^{-}+\mathrm{H}_{2} \mathrm{CO}_{3} \rightarrow \mathrm{CO}_{3}^{2-}+2 \mathrm{H}_{2} \mathrm{O} \\
& \mathrm{CO}\left(\mathrm{NH}_{2}\right)_{2}+2 \mathrm{H}_{2} \mathrm{O} \rightarrow \mathrm{CO}_{3}^{2-}+2 \mathrm{NH}_{4}^{+}
\end{aligned}
$$

The urease enzyme supplied will hydrolyze the urea to produce ammonia and carbamate (Eq. 1) whereby carbamate then decomposes spontaneously into ammonia and carbonic acid (Eq. 2). The ammonia is then hydrolyzed into ammonium and hydroxide ions thus increasing the $\mathrm{pH}$ of the sample, making carbonate precipitation favorable (Eq. 3). The carbonic acid dissociates into inorganic carbonates (Eq. 4-5) and supplying calcium chloride anhydrous $\left(\mathrm{CaCl}_{2}\right)$ will provide calcium ions that combine with the carbonate ions to precipitate calcite, $\mathrm{CaCO}_{3}$ (Eq.6).

$$
\mathrm{Ca}^{2+}+\mathrm{CO}_{2}^{2-} \rightarrow \mathrm{CaCO}_{3}
$$

The calcite generated from the chemical reaction is acting as the bonding and cementation agent for soil particles. The crystallographic forms of calcite affect the effectiveness of EICP treatment as different sizes, shapes, and distribution patterns can produce different strength responses of the biocemented soil [9]. Besides, factors such as type of biocementation solution, soil characteristics, treatment method, temperature, treatment concentration, $\mathrm{pH}$ level, and degree of saturation are also critical [6].

\section{Research Methodology}

\subsection{Soil Sampling}

Soil sampling was conducted at Lohan Dam where tailings were piped, routed, and deposited from the source, Mamut Copper Mine, located $8 \mathrm{~km}$ away [10]. The samples were collected at GPS coordinate of $6^{\circ} 0^{\prime}$ $45.936^{\prime \prime} \mathrm{N}, 116^{\circ} 44^{\prime} 20^{\prime \prime} \mathrm{E}$ from the depth of $0.5 \mathrm{~m}$ to 3.0 $\mathrm{m}$ of the soil profile.

\subsection{Geotechnical and Geochemical Properties}

The geotechnical properties determined were their natural moisture content, sieving analysis, Atterberg limits, $\mathrm{pH}$, specific gravity, and organic matter. The dry and wet sieving method was used to determine the particle size distribution of coarser and finer soil respectively. $\mathrm{pH}$ was measured by $\mathrm{pH}$ meter and specific gravity, permeability, and organic matter were measured according to British Standard.

Following the tests, the mine wastes were classified based on their particle size, particle distribution, and texture using two major classification systems; AASHTO and USCS. All laboratory tests were performed according to BS 1377: Part 2: 1990. The air-dried and powdered sample were then made into pressure, digested, and analyzed using an inductively coupled plasma optical emission spectrophotometer (ICP-OES) to determine the concentration of heavy metals and major elements. A scanning electron microscope (SEM) with a maximum magnification of about $1000 \mathrm{x}$ was used to generate highresolution images and precisely measures very small features on the surface of the sample. 


\subsection{Enzyme-Induced Calcite Precipitation Treatment}

The EICP solutions used in this study are made up of urease enzyme, urea, and calcium chloride anhydrous. Cementation solution of $0.5 \mathrm{M}$ concentration was made by mixing urea and calcium chloride anhydrous according to their molarity with distilled and deionized water until complete dissolution. The urease enzyme of $3 \mathrm{~g} / \mathrm{L}$ is added just before adding to the soil sample to avoid early precipitation of $\mathrm{CaCO}_{3}$. The urease enzyme and the chemical reagents were sourced from Fischer Scientific Company, United States, and have a purity of $99 \%$. The urease enzyme is plant-based, extracted from jack bean (Canavalia ensiformis) with the reported activity of 3500 $\mathrm{U} / \mathrm{g}$.

The cementation solutions were mixed with the samples, placed in permeability cells, and compacted at three-layer to achieve the densities relative to the optimum water content previously determined in the compaction test. Each layer of the mixture was gently tampered with to achieve the predetermined final height. The cell is then cured at different curing temperatures before a constant hydraulic conductivity test is performed according to BS1377. The series of the treatment are shown in Table 1 below;

Table 1. EICP Treatment Series

\begin{tabular}{|c|c|c|c|}
\hline Sample & $\begin{array}{c}\text { Relative } \\
\text { Density } \\
\mathbf{( \% )}\end{array}$ & $\begin{array}{c}\text { Curing } \\
\text { Temperature } \\
\left({ }^{\circ} \mathbf{C}\right)\end{array}$ & $\begin{array}{c}\text { Cementation } \\
\text { Solution } \\
\text { (M) }\end{array}$ \\
\hline Control & - & - & - \\
\hline EICP 1 & 70 & 5 & 0.5 \\
\hline EICP 2 & 70 & 15 & 0.5 \\
\hline EICP 3 & 70 & 25 & 0.5 \\
\hline EICP 4 & 80 & 5 & 0.5 \\
\hline EICP 5 & 80 & 15 & 0.5 \\
\hline EICP 6 & 80 & 25 & 0.5 \\
\hline
\end{tabular}

\subsection{Acid Digestion Test}

After hydraulic conductivity is completed, the samples were then tested for the calcium carbonate content (CCC), using Acid Washing Method. Samples were collected at three points (top, middle, and bottom), mixed with HCL acid to dissolve the calcium carbonate, then all the solution and insoluble solids were washed by distilled water on filter paper with a coarse pore size sieve (No 200) for 10 minutes. The purpose of the washing process is to remove all soluble calcium from the soil particles. Then the remaining particles were oven-dried and weighed. The CCC was calculated using Eq. 7

$$
\mathrm{CCC}=100-(\mathrm{B} / \mathrm{A}) \times 100
$$

Where;

$\mathrm{A}=$ Weight of soil prewashing

$\mathrm{B}=$ Weight of soil post washing

\section{Result and Discussion}

\subsection{Geotechnical Properties}

The distribution curve of Lohan Dam soil in Fig. 1 showed the dominant amount of coarse-grain particles at $70 \%$. This percentage is higher compared to wastes from other copper mines around the world but lower compared to the Mamut site where it originates [11]. For example, the study found that the average copper mine waste in the Philippines consists of $50 \%$ coarse [12], 30\% coarse in British Columbia [13], 55\% in Sarcheshmeh Iran [14], $20 \%$ coarse in Michigan [15], $60 \%$ coarse for average US slime [16] and 10\% coarse for British Columbia slime [17]. This shows that the size of mine copper waste particles depends on the milling size, feeding materials, hydro cyclone pressure, slurry density, and presence of water during the extraction process.

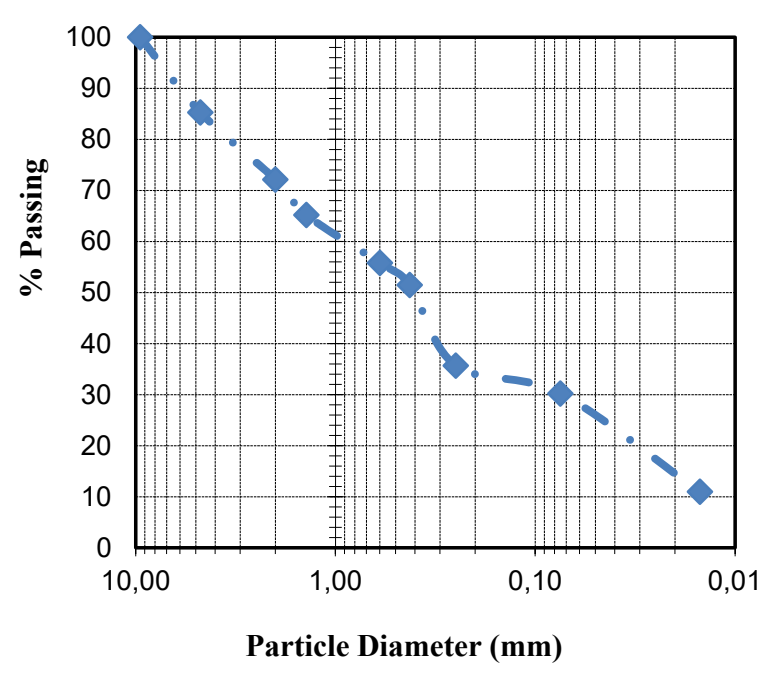

Fig. 1. Particle Distribution of Lohan Dam Soil

Classification by Unified Soil Classification System (USCS) indicates that Lohan Dam soil is SM with the presence of silt in a coarse grain that is predominantly sand. Using the American Association of State Highway and Transport Officials (AASHTO), it is classified as A4 , a fair to poor rate as road subgrade.

The consistency behavior of tailings can be grouped into coarser and finer than $0.074 \mathrm{~mm}$ (Sieve No 200). The coarser group, also known as 'sand tailings' exhibits nonplastic (NP) behavior while the finer group, also known as 'tailings slimes' may exhibit low plasticity. The acidic nature of the mine is evident in the $\mathrm{pH}$ value recorded between 4.53-6.18. The average organic content is relatively low with the value ranging from $0.15-1.27 \%$. As the organic content comes primarily comes from plant roots, this value may indicate that the soil is not conducive for vegetation and hence a challenge for stabilization method using phytoremediation method. This is supported by the fact that there are fewer high trees and plants observed here compared to the nearby area. 
Specific gravity test showed that on average, mine wastes have $\mathrm{G}_{\mathrm{S}}$ of 2.66-2.75, associated with heavy grained soil. Similar to the other processed mine waste soils, the Lohan Dam soil has a high maximum dry density and low cohesion but a high angle of friction. The engineering properties are shown in Table 2.

Table 2. Properties of Lohan Dam Soil

\begin{tabular}{|c|c|}
\hline Properties & Values \\
\hline \multicolumn{2}{|l|}{ Consistency Index } \\
\hline Liquid Limit, LL (\%) & 27.0 \\
\hline Plastic Limit, PL (\%) & 23.5 \\
\hline Plasticity Index, PI (\%) & 3.5 \\
\hline Liquidity Index, LI (\%) & 0.91 \\
\hline Activity (A) & 0.32 \\
\hline Average Natural water content (\%) & 26.68 \\
\hline Specific Gravity, Gs & $2.66-2.75$ \\
\hline $\mathrm{pH}$ & $4.35-6.18$ \\
\hline Maximum Dry Density, $\mathrm{kg} / \mathrm{m}^{3}$ & 1640 \\
\hline Optimum Water content, $\%$ & $16 \%$ \\
\hline The angle of friction, ${ }^{\circ}$ & $6-37$ \\
\hline Cohesion, $\mathrm{kN} / \mathrm{mm}^{2}$ & $0.04-0.1$ \\
\hline Organic content, $(\%)$ & $0 . .15-1.27$ \\
\hline
\end{tabular}

The SEM morphological analysis is shown in Fig. 2 (1000x) appears to be composed of powdered and hardened particles with dark brown color. Particles observed are well-rounded and spherical in shapes but some irregular-shaped are also observed.

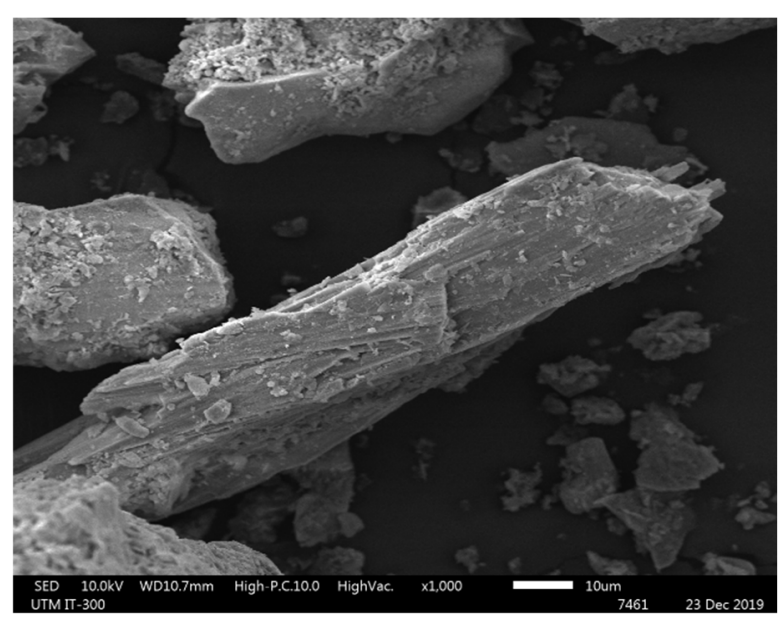

Fig. 2. Scanning Electron Magnetic of Lohan Dam Soil

\subsection{Geochemical Properties}

The level of heavy metals in soil samples collected from Lohan Dam are shown in Table 3. When compared to the standard of the Department of Environmental Malaysia (DOE) and Food and Agriculture Organization of the United Nations (FOA), the concentration (in $\mathrm{mg} / \mathrm{L}$ ) of arsenic, As (0.319), copper, Cp (4.337), and nickel, Ni $(0.376)$ are beyond the safe levels indicate the necessitate for treatment.
Table 3. Heavy Metal Contaminant of Lohan Dam Soil

\begin{tabular}{|l|l|l|l|l|}
\hline \multirow{2}{*}{$\begin{array}{l}\text { Heavy Metal } \\
\text { Elements }\end{array}$} & \multicolumn{4}{|c|}{ Contaminant Level (mg/L) } \\
\cline { 2 - 5 } & $\begin{array}{c}\text { Point } \\
\text { 1 }\end{array}$ & $\begin{array}{c}\text { Point } \\
\mathbf{2}\end{array}$ & $\begin{array}{c}\text { Point } \\
\mathbf{3}\end{array}$ & Average \\
\hline Arsenic, As & 0.315 & 0.319 & 0.323 & 0.319 \\
\hline Cadmium, Cd & -0.052 & -0.051 & -0.051 & -0.051 \\
\hline Cobalt, Co & -0.026 & -0.025 & -0.024 & -0.025 \\
\hline Chromium, Cr & 0.578 & 0.588 & 0.591 & 0.586 \\
\hline Copper, Cp & 4.287 & 4.327 & 4.396 & 4.337 \\
\hline Iron, Fe & 2926.2 & 2951.1 & 2916.9 & 2931.4 \\
\hline $\begin{array}{l}\text { Manganese, } \\
\text { Mn }\end{array}$ & 3.601 & 3.627 & 3.698 & 3.642 \\
\hline Nickel, Ni & 0.372 & 0.378 & 0.378 & 0.376 \\
\hline Lead, Pb & 0.508 & 0.554 & 0.541 & 0.535 \\
\hline Zinc, $\mathrm{Zn}$ & 0.546 & 0.56 & 0.56 & 0.555 \\
\hline
\end{tabular}

When the further chemical test is performed, it was found that the predominant compounds for the soil are quartz $\left(\mathrm{SiO}_{2}\right)$, orthoclase $\left(\mathrm{KAlSi}_{3} \mathrm{O}_{8}\right)$, and zinc-aluminum hexanedycarboxylate hydrate $\left(\mathrm{CH}_{3} \mathrm{AlO}_{5} \mathrm{Zn}\right)$. The qualitative analysis results are shown in Fig. 3.

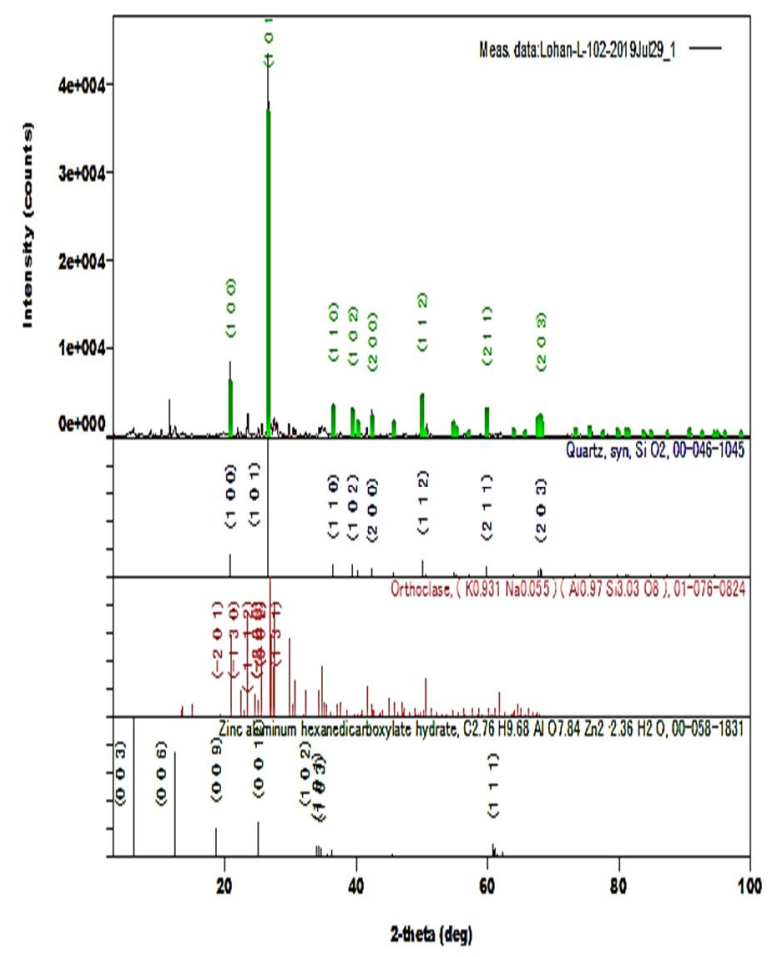

Fig. 3. Major Chemical Compound of Lahad Dam Soil

\subsection{Effects of EICP Treatment to the Hydraulic Conductivity}

The average hydraulic conductivity of the control sample indicates that soil has a 'medium' degree of permeability with a value between $10^{-3}$ and $10^{-1} \mathrm{~cm} / \mathrm{s}$, consistent with the soil description and classification in Section 4.1. Following 1, ' 3 and 7-day EICP treatment, almost all series measured an average value between $10^{-4}$ to $10^{-3}$, a reduction between $94-97 \%$. This indicates that the EICP treatment has changed the degree of permeability from 
'medium' to 'low', corresponding to the permeability of soil that is classified as very fine sand and mixtures of sand, silt, and clay. The reduction is shown in Fig. 4.

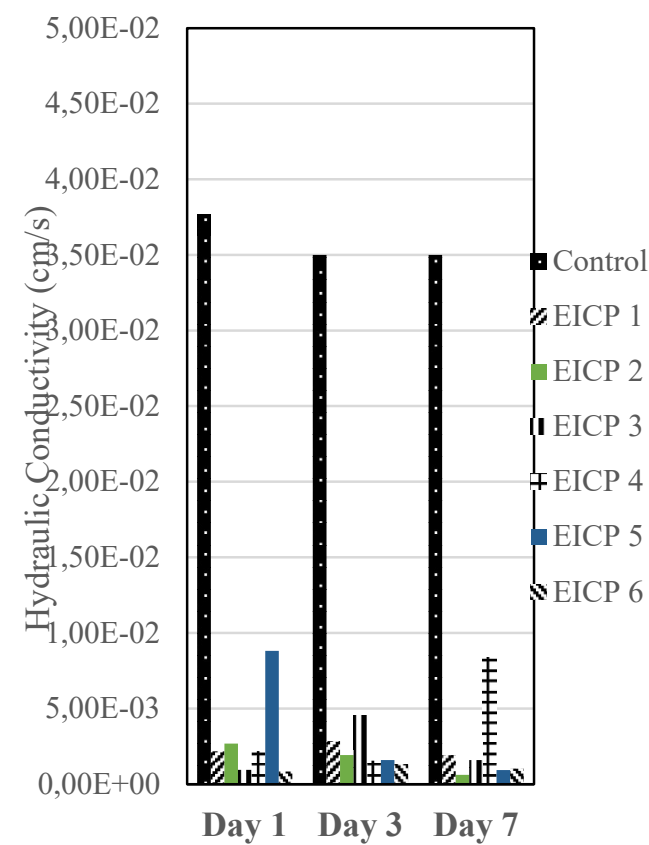

Fig. 4. Hydraulic conductivity of Lohan Dam soil

It is also noted that curing temperature is beneficial for a 1-day curing duration as shown by EICP 3 and EICP 6, where both samples were cured under temperature $25^{\circ} \mathrm{C}$ over the EICP 1 and EICP 4, where both samples were cured under temperature $5^{\circ} \mathrm{C}$. This indicates that the biocementation reaction is more effective under higher temperatures. The findings are similar to a previous study on the rate of urea hydrolysis for uncontaminated soils which reported that they are marginally higher in temperature closer to $30^{\circ} \mathrm{C}$ [18]. The finding is also consistent with a previous study on semi-arid tropical soil which stated that the optimum urease activity lies at approximately $60^{\circ} \mathrm{C}$, and the activity increased with increasing temperature from 10 until reaching the peak at $60^{\circ} \mathrm{C}[19]$.

On the other hand, the relative density of $70 \%$ and $80 \%$ show smaller differences in permeability, probably due to the mixing method selected i.e premixing rather than injection. While premixing allows uniform distribution of cementation solution to all the soil grain particles, the injection method has major disadvantages i.e uneven distribution of bacteria and localized cementation around the injection points leads to pore-clogging at the area near the injection points [6]. Therefore, it is speculated that the soil particle in $70 \%$ and $80 \%$ relative density were both uniformly treated, hence smaller differences in permeability reduction is observed.

\subsection{Effects of EICP Treatment on the Calcium Carbonate Content}

Before the EICP treatment, the CCC of untreated mine waste is $3.66 \%$ but the percentage increases to a value ranging 6.38-6.95\% after 1 day and 6.94-9.63 after 3 and 7 days, as shown in Fig. 5. This is observed for all series except for EICP 5 for Day 1. Hence, it can be stated that the amount of improvement in EICP treated soil is much related to the amount of induced calcium carbonate content [20] and the reduction in permeability of mine waste is corresponding to the amount of calcium carbonate content.

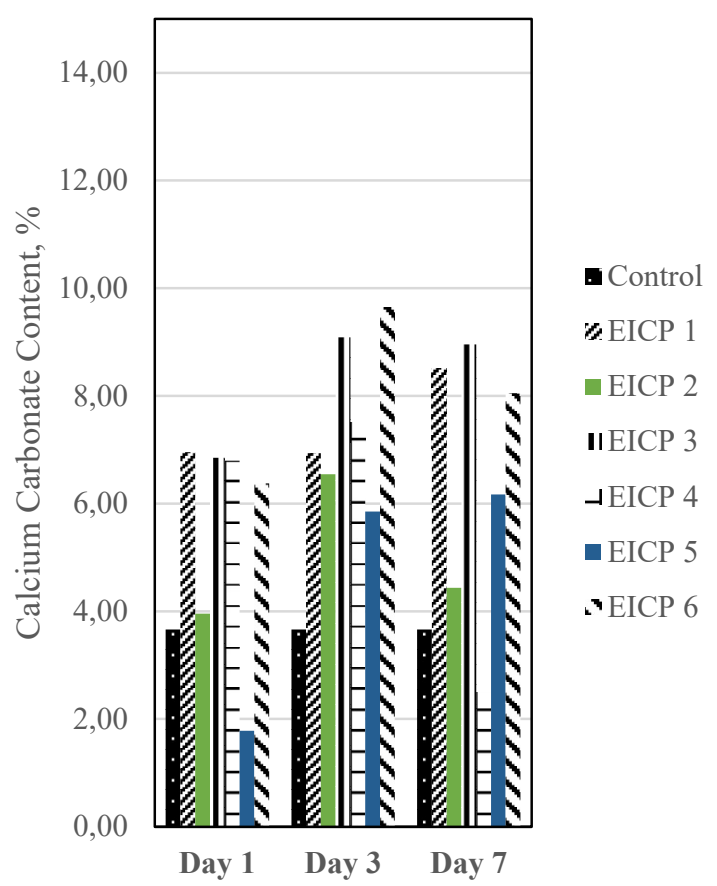

Fig. 5. Calcium Carbonate content of Lohan Dam soil

As is the case for the control sample, the lack of reduction in permeability can be explained by the low amount of calcium carbonate content, as shown in Figure. Before the treatment, the $\mathrm{CCC}$ is recorded as $3.60 \%$ but upon treatment, the range of $\mathrm{CCC}$ is between $1.46-4.10 \%$, lower than the value of mine waste.

\section{Conclusion}

A series of geotechnical test EICP treatments have been performed on heavy-metal contaminated soil from Lohan, Dam Sabah, and the following conclusion can be made;

1. Geotechnical, Lohan Dam soil is predominantly coarse grain soil of low plasticity, high specific gravity, and high permeability making them susceptible to land contamination. Soil is acidic in nature and its low organic content may indicate that stabilisition by neutralization and phytho-stabilization methods will be costly and not conducive.

2. Morphologically, all wastes appear to be composed of powdered and hardened particles with dark brown color. They contain a higher amount of irregularshaped particles but well-rounded and spherical are also observed. Their surfaces appear to be very smooth with no agglomeration between particles which indicates that without treatment, the strength value of 
the soil is low due to the weak bonding between the loose grain structure.

3. In terms of mineralogy, Lohan Dam soil wastes contain a high level of heavy metals beyond the safety level of the Department of Environmental Malaysia (DOE) and Food and Agriculture Organization of the United Nations (FOA) making them good candidates for EICP stabilization.

4. EICP treatment has changed the degree of permeability of the mine waste from 'medium' to 'low' corresponding to the amount of calcium carbonate content. While relative density shows the marginal effect, curing duration and temperature show a more significant impact.

This work was supported by the Ministry of Education Malaysia's Fundamental Research Grant Scheme [R. J130000.7851.5F256] and the High Impact Research Grant [Q. J130000.2451.04G57].

\section{References}

1. A.V. Patel, A Study on Geotechnical Properties of Heavy Metal Contaminated Soil. Paripex - Indian Journal of Research, 3 (6), 2 (2014).

2. V. D. Ent, A. and M. Edraki, Environmental Geochemistry of the Abandoned Mamut Copper Mine (Sabah) Malaysia. Environ Geochem Health, 40 (1), 19 (2016).

3. L. Hu, et al., Geotechnical Properties of Mine Tailings. Journal of Materials in Civil Engineering, 29 (2), 04016220 (2017).

4. A. Z. Rahman, et al., Influence of Amang (Tin Tailing) on Geotechnical Properties of Clay Soil. Sains Malaysiana, 41, 303-312 (2012)

5. W. Zuhairi, N.S. M. Pauzi, and H. A. Mutalib, Acid mine drainage, and heavy metals contamination at abandoned and active mine sites in Pahang. 55, 1520 (2009).

6. D. Mujah, M.A. Shahin, and L. Cheng, State-of-theArt Review of Biocementation by Microbially Induced Calcite Precipitation (MICP) for Soil Stabilization. Geomicrobiology Journal, 34 (6), 524-537 (2017).

7. Y. Luo, Study on the repair of heavy metal contaminated soil. IOP Conference Series: Earth and Environmental Science, 300, 032076 (2019).

8. A. S. Muhammed, et al., Influence of multiple treatment cycles on the strength and microstructure of biocemented sandy soil. International Journal of Environmental Science and Technology, (2021).

9. A. A. Qabany and K. Soga, Effect of chemical treatment used in MICP on engineering properties of cemented soils. Géotechnique, 63 (4), 9 (2013)

10. M. K. Azizli, , Y. T. Chee, and J. Birrel, Design of the Lohan Tailings Dam, Mamut Copper Mining Sdn. Bhd., Malaysia. Minerals Engineering, 8 (6), 705-712 (1995).

11. J. Makinda, et al., Geotechnical properties of unprocessed soil from abandoned Mamut mine in Sabah, Borneo. IOP Conference Series: Earth and Environmental Science, 708 (1), 012021 (2021)

12. R. G. R Salazar. Design, construction, and operation of the tailings pipelines and underwater tailings disposal system of Atlas consolidated mining and Development Corporation in the Philippines. in Proceeding of the 1st International Tailing Symposium. 1973. Miller Freeman, San Francisco.

13. E. Klohn, C. Maartman, Construction of Sound Tailings Dam by Cycloning and Spigotting. in Proceeding of the 1st International Tailing Symposium. 1973. Miller Freeman, San Francisco.

14. A. Shamsai, et al., Geotechnical Characteristics of Copper Mine Tailings: A Case Study. Geotechnical and Geological Engineering, 25 (5), 591-602 (2007).

15. F. Girucky, New tailings dam construction at White Pine. in Proceeding of the 1st International Tailing Symposium. 1973. Miller Freeman, San Fransisco.

16. R. Volpe, Physical and engineering properties of copper tailings, in American Society of Civil Engineers, ASCE: New York. p. 19. (1979).

17. K. H. Mittal, N.R.M., Parameters for the Design of Tailings Dams. Canadian Geotechnical Journal, 12 (2), 27 (1975)

18. M. Nemati, E. Greene, and G. Voordouw, Permeability profile modification using bacterially formed calcium carbonate: Comparison with enzymic option. 40, 925-933 (2005)

19. K. Sahrawat, Effects of temperature and moisture on urease activity in semi-arid tropical soil. Plant and Soil, 78, 401-408 (1984).

20. S. G. Choi, et al., Methods for Calcium Carbonate Content Measurement of Biocemented Soils. Journal of Materials in Civil Engineering, 29, 06017015 (2017). 